\title{
A case report of endophthalmitis three days after dental implant, one month after cataract surgery
}

\author{
Ming Chen ${ }^{1 *}$, Vernon Wong ${ }^{1}$ and Nathan Wilbanks ${ }^{2}$ \\ ${ }^{1}$ University of Hawaii, USA \\ ${ }^{2}$ University of Virginia, USA
}

\section{Case report}

A 74-year-old male underwent uncomplicated cataract surgery of the right eye one month prior. His postoperative visual acuity was 20/20. He had LenSx assisted cataract surgery without complication. The preoperative medications included Besifloxacin $0.6 \%$ eye drops twice daily for three days with postoperative eye drops including the same antibiotic for six weeks following surgery. Intraoperatively, the surgeon himself prepped and draped the eye in the usual sterile ophthalmic fashion with povidone-iodine drops for 3 minutes along with meticulously scrubbing the lids and lashes with povidone-iodine solution. Profuse irrigation in the eye was done before the incision.

One month after surgery, the patient presented with sudden mild discomfort, mild conjunctival injection, and decreased vision in the right eye. He denied trauma, recent surgery or hospitalization, fever, chills, or any other systemically infectious symptoms. He had a past medical history of hypertension, atrial fibrillation, coronary artery disease, myocardial infarction in 1999, and hypothyroidism. The past surgical history revealed that he had a pulmonary vein ablation in 2011, implantable cardioverter defibrillator in 2004, coronary artery stent in 1999, and appendectomy in 1963.

His complete medication list included enalapril, levothyroxine, metoprolol, warfarin, simvastatin, etodolac, and furosemide. His eye drops included Besifloxacin $0.6 \%$ twice daily, difluprednate $0.05 \%$ twice daily, and bromfenac $0.075 \%$ twice daily all to the right eye. The patient's social history revealed that he was a retired police officer and is a black belt in karate. He was a former everyday cigarette smoker until quitting in 1990. He drank approximately 6 bottles of beer and 6 shots of whiskey per week.

On the day of presentation, ocular examination showed his best corrected visual acuity to be 20/60 in the right eye and 20/30 in the left eye. Intraocular pressure was $9 \mathrm{mmHg}$ in the right eye and $11 \mathrm{mmHg}$ in the left eye. Slit lamp exam of the right eye revealed the following. There was mild conjunctival injection. There was mild corneal edema with Descemet's membrane folds. The anterior chamber showed about ten percent of layered hypopyon inferiorly with fibrin as shown in Figure 1. The posterior chamber intraocular lens was in good position. The fundus revealed vitreous haze with vitreous cells as shown in Figure 2.

\section{Management}

Immediate pars plana vitrectomy was performed. A vitreous specimen was collected and sent for culture. Intravitreal antibiotics were administered and the patient was placed on an intensive regimen of topical steroids. On the first day postoperative visit, the patient revealed that he had dental implant three days prior. He did not take the

preoperative oral antibiotics prior to the dental procedure as instructed by his dentist. Consequently, he was given oral clindamycin following the procedure. Meanwhile, the vitreous culture grew 1+Staphylococcus epidermidis that was sensitive to vancomycin and clindamycin but resistant to penicillin and oxacillin on the second postoperative day. Vision improved to $20 / 30$ in 3 weeks (as described in Figure 3) and improved to $20 / 20$ in 3 months.

\section{Discussion}

This case raises the question of an exogenous versus endogenous etiology. Tables 1-3 illustrate the differential diagnosis and treatment of exogenous and endogenous endophthalmitis. This case could represent exogenous endophthalmitis due to the onset within 6 weeks and likely poor compliance with antibiotic drops. The patient also admitted to over-activity with perspiration in the periocular region just days after surgery (as previously mentioned, the patient is a master black belt in karate). Staphylococcus epidermidis is coagulase-negative and a normal skin flora, known to be a common contaminant in collected specimens. It is of low virulence but can cause significant clinical ocular

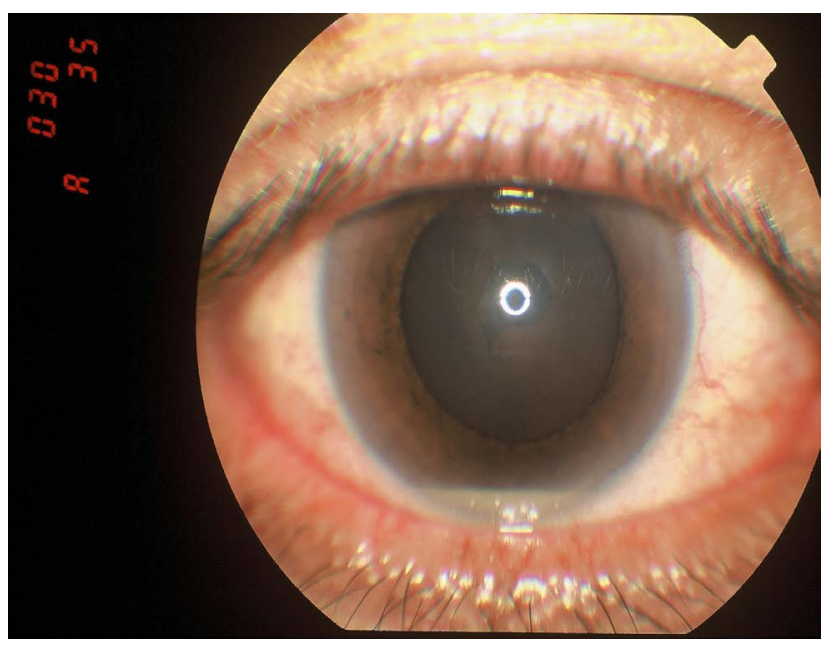

Figure 1. Slit lamp photo demonstrating ten percent hypopyon.

Correspondence to: Ming Chen, Department of Surgery, Division of Ophthalmology, John A. Burns School of Medicine, University of Hawai'i, Honolulu, HI, USA, E-mail: mingchen@hawaii.rr.com.

Received: September 22, 2017; Accepted: October 10, 2017; Published: October 13,2017 


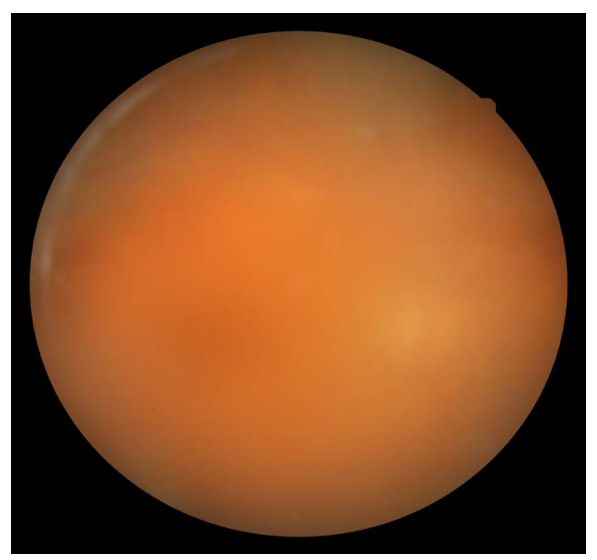

Figure 2. Fundus photo of the right eye demonstrating vitreous haze with heavy vitreous cells.

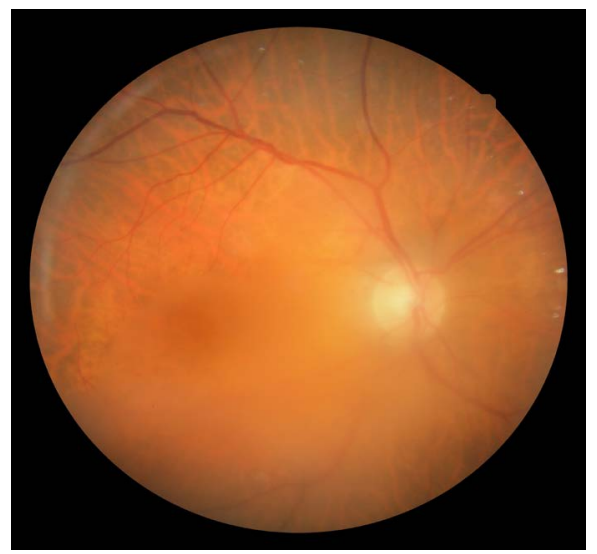

Figure 3. Fundus photo of right eye 3 weeks after vitrectomy. Vision improved to $20 / 30$ in 3 weeks and improved to $20 / 20$ in 3 months.

Table 1. Differential Diagnosis.

\begin{tabular}{|l|l|l|l|l|}
\hline $\begin{array}{l}\text { Infectious } \\
\text { Exogenous or } \\
\text { Endogenous }\end{array}$ & $\begin{array}{l}\text { Sterile } \\
\text { postoperative } \\
\text { inflammation }\end{array}$ & $\begin{array}{l}\text { Medication- } \\
\text { induced }\end{array}$ & Neoplastic & Autoimmune \\
\hline As table 2-3 & $\begin{array}{l}\text { Retained lens } \\
\text { material }\end{array}$ & Rifabutin & Leukemia & HLA-B27 \\
\hline & & & Bechet's Disease \\
\hline
\end{tabular}

Table 2. Etiology of Infectious Endophthalmitis.

\begin{tabular}{|l|l|}
\hline Exogenous & Endogenous \\
\hline Acute postoperative & Rare \\
\hline $\begin{array}{l}\text { Cataract } \\
\text { Travitreal injection }\end{array}$ & \\
\hline $\begin{array}{l}\text { Chronic postoperative } \\
\text { Cutibacterium acnes (formerly } \\
\text { Proprionibacterium acnes) } \\
\text { Bleb-associated }\end{array}$ & $\begin{array}{l}\text { Seeding of the eye during bacteremia or } \\
\text { fungemia }\end{array}$ \\
\hline
\end{tabular}

infection. Most infections are associated with a prosthetic device and immune compromise such as in this patient (implantable cardioverter defibrillator present since 2004). It has a 90-95\% resistance to penicillin and $80 \%$ resistance to methicillin. The empiric treatment is with vancomycin. There could have been a component of Staphylococcus epidermidis resistance to the topical antibiotics used in this case.

Endogenous endophthalmitis should also be considered given the onset of the infection right after a dental implant without prophylactic antibiotic coverage. Dental procedures are theorized to cause transient septicemia that can cause seeding elsewhere in the body. Of note, the
Table 3. Signs/Symptoms and Treatment.

\begin{tabular}{|l|l|}
\hline Exogenous & Endogenous \\
\hline Acute postoperative is the most common & $\begin{array}{l}2-8 \% \text { of endophthalmitis cases } \\
\text { Most common sites of primary infectious } \\
\text { source: } \\
\text { Endocarditis, abdominal abscess, urinary } \\
\text { occur within } 6 \text { weeks of surgery, } 75 \% \\
\text { tract infection, indwelling catheter, dental } \\
\text { work }\end{array}$ \\
\hline Hypopyon and vitritis & Hypopyon and vitritis \\
\hline $\begin{array}{l}\text { Coagulase-negative staphylococci } 70 \%, S . \\
\text { aureus } 10 \% \text {, Streptococci } 10 \%\end{array}$ & $\begin{array}{l}\text { Bacteria: Streptococci } 30-50 \%, \text { S. aureus } \\
25 \% \text {, gram-negative bacilli } 30 \% \\
\text { Fungus: Candida }\end{array}$ \\
\hline $\begin{array}{l}\text { Treatment as per the Endophthalmitis } \\
\text { Vitrectomy Study } \\
\text { 1.Vitrectomy or vitreous tap } \\
\text { 2.Intravitreal antibiotics } \\
\text { - Vancomycin } 1 \mathrm{mg} \\
\text { - Ceftazidime } 2.25 \mathrm{mg} \text { or Amikacin } 0.4 \mathrm{mg}\end{array}$ & $\begin{array}{l}\text { Systemic antibiotics } \\
\text { Vitrectomy and intravitreal antibiotics }\end{array}$ \\
\hline
\end{tabular}

patient's implantable cardioverter defibrillator was found to fail by his cardiologist shortly after these events. This could represent coincidence or could be related to the events in question.

The surgeon did his own meticulous prep using povidone-iodine $5 \%$ drops, povidone-iodine scrub, and povidone-iodine solution for the case. In addition, the retina surgeon reported the corneal wound was healed and tight when the vitrectomy was performed. This further argues against a case exogenous endophthalmitis. There have been cases reported in the literature demonstrating that many eye infections have been associated with dental work [1-7]. This case was treated promptly according to the Endophthalmitis Vitrectomy Study ${ }^{8}$ for exogenous endophthalmitis while also covering with systemic antibiotics for endogenous endophthalmitis and ultimately with a good result in the end.

This case has changed my practice. Patients who are scheduled to have intraocular surgery will be informed to postpone dental work for at least six weeks. Also, reinforcement of using pre- and postoperative antibiotic drops and less physical activities in the postoperative period will be instructed to patients.

\section{References}

1. Lamont M, Booth A (2006) Post-traumatic endophthalmitis following penetrating injury with dental needle. Eye 20. 981-982.

2. Subramanian M, Topping T (2003) Endogenous Endophthalmitis after Routine Dental Cleaning, Arch Ophthalmol 121: 576-577.

3. Goldstein JL (2004) How a jolt and a bolt in a dentist's chair revolutionized cataract surgery. Nat Med 10: 1032-1033. [Crossref]

4. Paster BJ, Boches SK, Galvin JL, Ericson RE, Lau CN, et al. (2001) Bacterial diversity in human subgingival plaque. J Bacteriol 183: 3770-3783. [Crossref]

5. Tsai TH, Yang CH, Yang CM, Chen MS (2005) Endogenous endophthalmitis with sub retinal abscess after dental procedures. J Formos Med Assoc 104: 47-49. [Crossref]

6. Ogurel T, Onaran Z, Ogurel R, Örnek K, (2015) Endophthalmitis after tooth extraction in a patient with previous perforating eye injury. Pan Afr Med J 20: 72. [Crossref]

7. Shovlin J (2010) Although quite rare, dental work can cause problems with cataract surgery or corneal transplantation. Review of Optometry October 16.

8. [No authors listed] (1995) Results of the Endophthalmitis Vitrectomy Study. A randomized trial of immediate vitrectomy and of intravenous antibiotics for the treatment of postoperative bacterial endophthalmitis. Endophthalmitis Vitrectomy Study Group. Arch Ophthalmol 113: 1479-1496. [Crossref]

Copyright: (C2017 Chen M. This is an open-access article distributed under the terms of the Creative Commons Attribution License, which permits unrestricted use, distribution, and reproduction in any medium, provided the original author and source are credited. 